\title{
EXPLORING INDONESIAN EFL LEARNERS' METAFUNCTION COMPETENCE AND THEIR CRITICAL READING
}

\author{
Nani Ronsani Thamrin \\ Department of English Education, University of Kuningan, Indonesia \\ Email: nani_cute@yahoo.com \\ Jaruki Andriansyah Maulana \\ Department of English Education University of Kuningan, Indonesia \\ Email: prince_kafa@yahoo.com
}

APA citation: Thamrin, N. R. \& Maulana, J. A. (2015). Exploring the relationship between students' metafunction competence and their critical reading. Indonesian EFL Journal, 1(1), 70-80

Abstract: This study explores the relationship between students' metafunction competence and their critical reading. This study uses mixed method approach to discover deep and whole comprehension of the research problem. The five undergraduate students who have attended functional grammar class are purposively involved. This study shows that students' metafunction competence and their critical reading positively correlate. In the other words, the students' metafunction competence develops their critical reading ability. It is corresponding with the conclusion which is drawn by Bumela (2011) that the initial formation of meaning is also largely influences by reader's expectations and background knowledge. Hereby, students' metafunction competence plays as students' background knowledge to recognise the features of the texts and identify the metafunctions of the texts which is beneficial as the departure for critical reading.

Keywords: students' metafunction competence, critical reading.

\section{INTRODUCTION}

This study is intended to explore the relationship between students' metafunction competence and their critical reading. It examines the influence of students' metafunction competence level toward their competence to read the text critically. In addition, it also tries to discover the correlation of them. This study is inspired by the works of Maulana in "Exploring the Critical Reading Sheet: A Tool for Students' Meaning Making Practice" (2014); and Bumela's work entitled "The Metafunctions Revealed: EFL Learners' Experience in Making Sense of the Text" (2011). Maulana (2014) investigated the critical reading sheet (the list of guiding questions offered as an instrument to analyse the text around the notion of metafunctions - ideational, interpersonal, and textual) developed by Eggins (1994), Knapp \& Watkins (2005),
Thompson (2004) and Wallace (2003) as a tool for students meaning making practice. He tried to reveal how the critical reading sheet helps EFL learners to make sense of the text as it offers them tool to generate deep comprehension and interpretation of the text. The emphasis of his conclusion is that the critical reading sheet gives them the ability to recognise the features of the texts and identify the metafunctions of the texts. Therefore, it triggers EFL learners to approach, make sense and read the text critically.

In addition, Bumela (2011) captured the English as foreign language learners' experience in making sense of the text. He emphasized that reading is a discursive activity which is influenced by the previous textual experiences. The quality of interpretation is always affected by the background knowledge of readers, the ability 
in recognizing the features of the texts, and, of course, the ability to identify the metafunctions of the texts. Critical reading means that a reader applies certain processes, models, questions, and theories that result in enhanced clarity and comprehension. There is more involvement both in effort and understanding in a critical reading than in a mere skimming of the text. The importance of critical reading of the text to get at deep structure, as proposed by Learning Development at the University of Leicester (2009), is because during the research and writing process, the author(s) will have made many decisions and each of these decisions is a potential topic for examination and debate, rather than for blind acceptance. In addition, authors design the texts for specific audiences. Thus, readers need to be prepared to step into the academic debate and to make their own evaluation of how much they are willing to accept what they read. Importantly, a practical starting point of critical reading, therefore, is to consider anything the readers read not as fact, but as the argument of the writer. Taking this starting point, the readers will be ready to engage with the text by zooming in and out, asking questions, and making decisions as they read the texts (Anderson, 2011).

The aim of critical reading is not to find fault, but to assess the strength of the evidence and the argument. It may include the context of idea, context of culture, and context of situation of the text production. It is just as useful to conclude that a study, or an article, presents very strong evidence and a well-reasoned argument, as it is to identify the studies or articles that are weak.

Learning Development at the University of Leicester (2009) pointed that there are five most characteristic features of critical reading. Firstly, readers can examine the evidences or arguments presented. Secondly, readers check out any influences on the evidences or arguments. Thirdly, readers check out the limitations of study design or focus. Fourthly, readers examine the interpretations made. Lastly, readers decide to what extent the readers are prepared to accept the authors' arguments, opinions, or conclusions.
Functional grammar reveals that every single text is grammaticalised in nature by the writer/author to meet particular purposes (Bumela, 2011). Consequently, the text does not merely appear as it is, but it bears based on the writer's perspective toward the subject matter, with its specific purposes and for the specific audiences. In the other word, the construction of the text is politicized. Therefore, to become good readers, students have to possess good reading competence to discover what appears and what lies behind the texts.

Functional grammar offers the students reading procedures to reveal the metafunction of the text designed to arm the students with competences to discover and comprehend how grammar is used in particular contexts and how grammatical choices are meaningful choices (Jones \& Locke 2011). Those competences to reveal the metafunction of the text is what is called students' metafunction competence.

The metafunction is three types of meanings simultaneously constructed within the text: (1) ideational meanings; (2) interpersonal meaning; (3) and textual meaning (Eggins 1994; Gerot \& Wignell 1994; Halliday 1985). The ideational metafunction refers to the function for construing human experience which is the means by which readers make sense of reality (Halliday, 1985). It is what Eggins calls the carrier of the content of the talk. The analysis of a text from the perspective of the ideational metafunction involves inquiring into the choices in the grammatical system of transitivity including process types, participant types, and circumstances. Process types refers to the types of verbs used in the texts (material, relational, mental, behavioral, verbal, existential), participant refers to the name(s) of specific names or things as apparent in the clause, and circumstances commonly refers to specific places and times which occur in the beginning or the end of the clause.

The interpersonal metafunction relates to a text's aspects of tenor or interactivity (O'Halloran, 2006). Like field, tenor comprises three component areas including the speaker/writer persona, social distance and relative social status (Coffin, 2006). 
Interpersonal metafunction is fundamentally realized through the system of mood and modality. Mood refers to the forms of the clauses - declarative, interrogative, imperative -, while the modality refers to the degree of commitment of the speaker/writer and hearer/reader towards the things he/she says. The modal verbs such as must, can, and should definitely depict different degrees of obligation.

The textual metafunction relates to mode that is the internal organisation and communicative nature of a text ( $\mathrm{O}^{\prime}$ Halloran, 2006). This comprises textual interactivity, spontaneity and communicative distance (Coffin, 2006). The grammar of textual meaning is chiefly realized within the themerheme system. Theme is what occurs in the beginning of the clause. It is usually apparent in the Subject and Finite of the clause, while rheme is what occurs after the theme. A reader needs to be completely aware of the types of themes constructed by the author so that he/she can mark out the given/new information rooted in a clause (Bumela, 2011).

\section{METHOD}

This study uses mixed method approach in which qualitative approach is used to understand and discover what lies behind the phenomenon while quantitative approach is to prove positive correlation between students' metafunction competence and their critical reading. The five respondents who have attended functional grammar class from English Education Department students at University of Kuningan, Indonesia, are purposively chosen. The data source used to test students' metafunction competence and their critical reading taken from the transcripts of the two selected articles from The Jakarta Post entitled SBY asks Pertamina to review LPG price hike and Govt accused of lying over LPG price hike. The main reason why newspaper articles are chosen is because, as Lehtonen (2000) put it, newspaper descriptions of reality are always produced from a certain perspective.

The data in this study gained through triangulation technique consisting of two tests and semi-structured interview. The first test is in form of text response designed to measure students' metafunction competence. The second test in form of critical reading test aimed at measuring students' critical reading and thus exploring the relationship between students' metafunction competence and their critical reading. Semi-structured interview given to discover how students' metafunction competence helps them to read the text critically. Descriptive analysis used to describe the basic features of the data while Pearson Correlation is applied using SPSS Statistics to reveal the correlation between students' metafunction competence and their critical reading.

\section{FINDINGS AND DISCUSSION Qualitative Analysis}

The five respondents possess different category of metafunction competence which correspondingly influence their critical reading. It is represented by how they address every single question provided in the critical reading sheet traced in Figure 1.

It can be seen from figure 1 that the five respondents possess different level of metafunction competence. \#R1 and \#R2 are categorized into students who possess high category of metafunction competence although significantly they get unbalanced scores in which \#R1 gets 90 while \#R2 gets 70. Generally, \#R1 can identify and interpret every single aspect of every metafunction competence while \#R2, in some occasions, are failed to interpret what the findings mean. Differently, \#R3 and \#R4 belong to the student with medium metafunction competence. \#R3 and \#R4 mainly can identify every single aspect of every metafunction competence but, unfortunately, they are failed in interpreting the meaning lies behind it. \#R5 has low metafunction competence. \#R5 has the competence to identify aspect of metafunction competence but sometimes he is also failed to do it. In addition, \#R5 cannot interpret what the findings mean.

As a matter of this study, the relationship between the students' metafunction competence and their critical reading is the core discussion. To address this objective, the students are brought to answer the following five guiding questions: (1) How 
are the two titles constructed by the authors? (2) How are the events portrayed in the two articles? (3) How are the people represented in the articles? (4) How do the authors evaluate the events depicted in the two selected articles? and (5) How are the events concluded in the events? In responding the five guiding questions, the five respondents use and reveal different category of critical reading. It is represented by how they address every guiding question recorded in figure 2.

\section{No Competence}

$\begin{array}{lr} & \text { Score } \\ \text { \#R1 } & \text { \#R2 }\end{array}$

\section{Ideational Metafunction Competence}

(Competence to reveal the writer's/speaker relationship to the subject matter. What the text is about. The language used to talk about the world. Who did what to whom)

\begin{tabular}{cllllll}
\hline 1 & Identifying and interpreting participants of the text & 2 & 2 & 2 & 2 & 1 \\
\hline 2 & Identifying and interpreting processes of the text & 2 & 1 & 1 & 1 & 1 \\
\hline 3 & Identifying and interpreting circumstances of the text & 2 & 2 & 2 & 2 & 1 \\
\hline 4 & Identifying and interpreting causation of the text & 1 & 1 & 1 & 0 & 0 \\
\hline
\end{tabular}

\section{Interpersonal Metafunction Competence}

(Competence to reveal how the writer indicates his/her relationship with the reader and what his/her attitude to the subject matter of the text is, what parts of grammar can be identified as enablers of interaction and who is taking part?)

\begin{tabular}{llllll}
\hline 5 & Identifying and interpreting person of the text & 2 & 1 & 1 & 0 \\
\hline 6 & Identifying and interpreting mood of the text & 2 & 2 & 2 & 2 \\
\hline 7 & Identifying and interpreting modality of the text & 2 & 2 & 2 & 2 \\
\hline 8 & Identifying and interpreting appraisal of the text & 1 & 0 & 0 & 0 \\
\hline Textual Metafunction Competence
\end{tabular}

Textual Metafunction Competence

(Competence to reveal what role language is playing in the interaction, how the text is organized, what kind of text is being made, and what the channel of communication is)

\begin{tabular}{|c|c|c|c|c|c|}
\hline 9 Identifying and interpreting theme of the text & 2 & 2 & 1 & 1 & 1 \\
\hline 10 Identifying and interpreting cohesion of the text & 2 & 1 & 1 & 0 & 0 \\
\hline Total & 18 & 14 & 13 & 10 & 6 \\
\hline Score & 90 & 70 & 65 & 50 & 30 \\
\hline Percentage & $90 \%$ & $70 \%$ & $65 \%$ & $50 \%$ & $30 \%$ \\
\hline Category & 胥 & 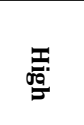 & 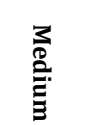 & 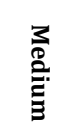 & $\sum_{i}^{5}$ \\
\hline
\end{tabular}

Figure 1. The students' metafunction competence analysis

\begin{tabular}{|c|c|c|c|c|c|c|}
\hline \multirow[b]{2}{*}{ No } & \multirow[b]{2}{*}{ Characteristics of Critical Reading } & \multicolumn{5}{|c|}{ Score } \\
\hline & & \#R1 & $\begin{array}{c}\mathbf{R} \\
\mathbf{2}\end{array}$ & \#R3 & \#R4 & \#R5 \\
\hline 1 & Readers examine the interpretations made. & 2 & 1 & 1 & 1 & 0 \\
\hline 2 & Readers will examine the evidences or arguments presented. & 2 & 1 & 1 & 1 & 1 \\
\hline 3 & Readers check out the limitations of study design or focus. & 2 & 1 & 1 & 1 & 1 \\
\hline 4 & Readers check out any influences on the evidences or arguments. & 1 & 1 & 1 & 0 & 0 \\
\hline 5 & $\begin{array}{l}\text { Readers decide to what extent the readers are prepared to accept the } \\
\text { authors' arguments, opinions, or conclusions. }\end{array}$ & 1 & 2 & 1 & 1 & 1 \\
\hline \multicolumn{2}{|c|}{ Total } & 8 & 6 & 5 & 4 & 3 \\
\hline \multicolumn{2}{|c|}{ Score } & 80 & 60 & 50 & 40 & 30 \\
\hline \multicolumn{2}{|c|}{ Percentage } & $\begin{array}{l}80 \\
\%\end{array}$ & $\begin{array}{l}60 \\
\%\end{array}$ & $50 \%$ & $\begin{array}{l}40 \\
\%\end{array}$ & $30 \%$ \\
\hline \multicolumn{2}{|c|}{ Category } & 韋 & 录 & 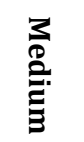 & 录 & $\sum^{5}$ \\
\hline
\end{tabular}


It is seen from figure 2 that different category of students' metafunction competence directly influences their critical reading category. Figure 3 captures how the respondents address the first guiding question aimed at identifying whether the respondents read critically by taking a careful look at the titles of the texts. As suggested by Bumela (2011), a title can mean a lot as it does not only tell us the topic of the texts, but also it leads us to trace the realm of meanings of the texts.

The responses given indicate whether or not the five respondents can examine the interpretations made by the author. Seeing carefully to the two titles of the text, \#R1 is successful to examine the interpretation made by the author. \#R1 sees that the two titles are grammatically constructed. This is along with Halliday theory (1985) that the text is grammaticalised. If the second title implies how the government is blamed for LPG price hike, then the first title, reports how the government defense from public opinion that LPG price hike is government policy, Interestingly, \#R1 is the only respondent who can reveal that the two articles are written by the same writer and see the relation between the two articles by taking careful attention on the time release. \#R2, \#R3, and \#R4 seem unsuccessful in examining the interpretation made by the author. \#R2 actually evaluates the construction of the two titles but unfortunately there is no further explanation about the judgment by providing any textual evidence. \#R3 does the same thing. \#R3 makes her own judgment on the titles but it is lack of elaboration. Similarly, \#R4 can evaluate that the titles delivers some important information but she cannot reveal what lies behind the two titles. \#R5 just rewrites the two titles of the text. There is neither explanation about the interpretation made by the author nor his own evaluation of the titles.

\begin{tabular}{|c|c|c|}
\hline \#R & Response on Text 1 & Response on Text 2 \\
\hline \#R1 & $\begin{array}{l}\text { The title is politicised. The writer supports } \\
\text { president and gives positive view about president } \\
\text { and government. }\end{array}$ & $\begin{array}{l}\text { The title seems to be political seen from the use of } \\
\text { words "accused" and "lying over" indicating hidden } \\
\text { facts and contrary arguments. The writer gives bad } \\
\text { image for president. The second title is first in time } \\
\text { release. But, what is more interesting is that these } \\
\text { articles written by the same writer. }\end{array}$ \\
\hline \#R2 & $\begin{array}{l}\text { The title is good and covers the content of the } \\
\text { article. }\end{array}$ & $\begin{array}{l}\text { The title is constructed in the form that will bring us to } \\
\text { the pros and cons. }\end{array}$ \\
\hline \#R3 & $\begin{array}{l}\text { The title is in declarative mood informing a } \\
\text { particular issue. }\end{array}$ & $\begin{array}{l}\text { The title tells how government is accused to } \\
\text { manipulate LPG price hike policy. }\end{array}$ \\
\hline \#R4 & $\begin{array}{l}\text { The title tells about SBY who asks pertamina to } \\
\text { review LPG price hike. }\end{array}$ & $\begin{array}{l}\text { The title tells how government accused of lying over } \\
\text { LPG price hike. }\end{array}$ \\
\hline \#R5 & $\begin{array}{l}\text { The title is SBY asks pertamina to review LPG } \\
\text { price hike. }\end{array}$ & The title is accused of lying over LPG pr \\
\hline
\end{tabular}

Figure 3. Respondents' responses on the first guiding question

However, the five respondents have examined the interpretation made by the author. Their responses can generally reveal the ideation of the text, what the text is about. In other words, they identify who does what to whom in what circumstance. The only respondent who seems failed in critically understand the title is \#R5. He neither provides any examination toward the title nor appropriate textual evidences.

The students' responses on the second guiding question recorded in figure 4 .
The responses given indicate whether or not the five respondents can examine the evidences or arguments presented by the author. \#R1 attempts to examine the evidences or arguments presented by the author correctly. She can evaluate the portrayal of the events and identify the focus of interest or focus event in the two articles. \#R2 writes that the events which become the focus of interest in the first article is the government (president SBY) asked pertamina to review LPG price hike and government gave the time to review it for about 24 hours. 
While in responding to the second article, she writes that the focus of interest is that the government was being accused by the citizen about LPG price hike. In this context, \#R2 seems successful to discover the portrayal of the events with no specific evaluation on how the events are portrayed. In contrast, \#R3 tends to critically look at the portrayal of the events. She sees that the first article is constructed in the positive sense while the second one is in negative sense. The only missing point is that how the events are portrayed positively or negatively. There is no further explanation and textual evidence. \#R4 and \#R5 write that the events in the first and second articles are chronologically portrayed. Unwillingly, there is no explanation on the types of events described in the articles.

\begin{tabular}{cll}
\hline \#R & \multicolumn{3}{c}{ Response on Text 1 } & \multicolumn{1}{c}{ Response on Text 2 } \\
\hline \#R1 & $\begin{array}{l}\text { The events are chronologic and strong to support each } \\
\text { other. The president's statements support to } \\
\text { successfully help government to defense and tackle } \\
\text { blame from citizen. }\end{array}$ & $\begin{array}{l}\text { Thents seem more realistic, because Bambang } \\
\text { makes the events portrayed clearly and logically. } \\
\text { mand }\end{array}$ \\
\hline \#R2 & $\begin{array}{l}\text { The government asked Pertamina to review LPG price } \\
\text { hike and they gave for about 24 hours to review it. }\end{array}$ & The government was being accused by the citizen. \\
\hline \#R3 & The events are portrayed in the positive senses. & The events are portrayed in the negative senses. \\
\hline \#R4 & The events are chronological. & The events are chronological. \\
\hline \#R5 & The events are chronological. & The events are chronological. \\
\hline
\end{tabular}

Figure 4: Respondents' Responses on the Second Guiding Question

It seems that the respondents can mainly examine the evidences or arguments presented by the author correctly. This tends to help them to reach critical comprehension on how the text is constructed, whether the text is coherent or not. Although in some cases, they still have not supported their judgment by sufficient explanation and textual evidences.

The students' responses on the third guiding question traced in figure 5.

\begin{tabular}{lll}
\hline \#R & \multicolumn{1}{c}{ Response on Text 1 } & \multicolumn{1}{c}{ Response on Text 2 } \\
\hline \#R1 & $\begin{array}{l}\text { The writer interprets the people in a positive } \\
\text { side. }\end{array}$ & The writer interprets the government in a negative side. \\
\hline \#R2 & The writer provides good image of president. & $\begin{array}{l}\text { Bambang looks brave and great explaining lie of } \\
\text { president and government. }\end{array}$ \\
\hline \#R3 & $\begin{array}{l}\text { The people or participants represented in the } \\
\text { article were clear enough. SBY is as the major } \\
\text { participant. }\end{array}$ & $\begin{array}{l}\text { Bambang Soesatyo is the major participant; Hatta } \\
\text { Rajasa and Jero Wacik are minor participant; and SBY is } \\
\text { the invisible participant. }\end{array}$ \\
\hline \#R4 & The article presents good image of government. & The article presents bad image of government. \\
\hline \#R5 & The writer focuses on presidents and pertamina. & $\begin{array}{l}\text { The writer focuses on president, pertamina, Hatta } \\
\text { Rajasa and Jero. }\end{array}$ \\
\hline
\end{tabular}

Figure 5: Respondents' responses on the third guiding question

The responses given indicate whether or not the five respondents can check out the limitations of study design or focus. It investigates what becomes the priority or the focus. \#R1 writes that the participant, especially the presidents, is described positively. The president is described as one who is responsible for LPG price hike policy by taking early action where the president asks Pertamina to review the regulation. In contrast, in responding to second article, he evaluates that president is guilty. He is described as the one who lies over LPG price hike policy regarding pertamina is stateowned company. In this context, the writes quotes statements from Bambang as a member of the House of Representatives' Commission III overseeing legal affairs, with his bravery and greatness to explain lie of president and government over LPG price hike. \#R2 and \#R4 implies the same thing from their responses. They argue that the focus of the first article is that the government is not guilty on the release of LPG price hike policy. 
Therefore, the presentation of the president is positive. In contrast, they say that the focus of the second article is government lie over LPG price hike policy. Therefore, the presentation of the government is negative. Unwillingly their arguments on the positive and negative description not explicitly described. \#R3 can actually identifies who the main participant is. Unfortunately, the participant who becomes the focus of interest itself is not described well. \#R5 writes that, in the first article, the writer focuses on presidents and pertamina. While in the second article, the writer focuses on president, pertamina, Hatta Rajasa and Jero. \#R3 also can identify the focus of the two articles but unwillingly, the further explanation is not explained.

In conclusion, the five respondents have different capacity to check out the limitations of study design or focus. They mainly can identify the focus, but seem failed to interpret how the focus is limited.

The students' responses on the fourth guiding question presented in figure 6 .

\begin{tabular}{rll}
\hline \#R & \multicolumn{1}{c}{ Response on Text 1 } & \multicolumn{1}{c}{ Response on Text 2 } \\
\hline \#R1 & The writer looks wise and kind to describe president. & $\begin{array}{l}\text { The writer looks passionate to prove the lie and } \\
\text { conspiration in the government. }\end{array}$ \\
\hline \#R2 & The author evaluates that the president is good. & $\begin{array}{l}\text { The author evaluates that the president is the one } \\
\text { who introduced LPG price hike, not Pertamina. }\end{array}$ \\
\hline \#R3 & The author evaluates that the president is not guilty. & The author evaluates that the president is guilty. \\
\hline \#R4 & \multicolumn{2}{c}{ No response } \\
\hline \multicolumn{3}{r}{ No response } \\
\hline
\end{tabular}

The responses indicate whether or not the five respondents can check out any influences on the evidences or arguments. This investigates how the author evaluate the events (the focus of interest) depicted in the two selected articles. \#R1 writes that for the first title, the writer looks wise and kind to describe president. While for the second title, the writer looks passionate to prove the lie and conspiration made by the government. From this response, \#R1 is rather focusing on the whole idea of the articles to focusing on how the author's perspective influences the evidences or arguments presented in the articles that should be taken care more. In almost same response \#R2 and \#R3 tend to critically evaluates how the author's perspective influences the evidences or arguments presented in the articles. They can identify that in the first article the author evaluates that the president is not guilty which is in contrast to the second article.

Unfortunately, they do not give any further explanation and provide any textual evidence. In contrast, \#R4 and \#R5 give no response to the fourth guiding questions. They seem confused to identify how the author evaluate the events depicted in the two selected articles.

In brief, the five respondents tend to be confused to check out any influences on the evidences or arguments. Only \#R1, \#R2 and \#R3 who are almost able to do it.

The students' responses on the fifth guiding question recorded in figure 7 :

\begin{tabular}{cll}
\hline \#R & \multicolumn{1}{c}{ Response on Text 1 } & \multicolumn{1}{c}{ Response on Text 2 } \\
\hline \#R1 & $\begin{array}{l}\text { The writer concludes that the events can be solved } \\
\text { by consultation of many sides/people. }\end{array}$ & $\begin{array}{l}\text { The writer argues that the most important person to } \\
\text { decide LPG price hike policy is president. }\end{array}$ \\
\hline \#R2 & $\begin{array}{l}\text { The author concludes that a consultation with BPK } \\
\text { and related ministers is needed. }\end{array}$ & $\begin{array}{l}\text { The author concludes that Hatta and Jero must have } \\
\text { consulted with President Yudhoyono. }\end{array}$ \\
\hline \#R3 & Pertamina should review LPG price hike. & $\begin{array}{l}\text { Pertamina should classify the review of LPG price } \\
\text { hike to limit the misunderstanding between citizen } \\
\text { and government. }\end{array}$ \\
\hline \#R4 & $\begin{array}{l}\text { The writer concludes that Pertamina should review } \\
\text { LPG price hike. }\end{array}$ & $\begin{array}{l}\text { The writer concludes that government lies over LPG } \\
\text { price hike. }\end{array}$ \\
\hline \#R5 & $\begin{array}{l}\text { The author concludes that BPK also recommended } \\
\text { Pertamina to increase the price of 12-kg LPG canisters } \\
\text { to contain, or at least to reduce, its financial losses. }\end{array}$ & $\begin{array}{l}\text { The author concludes that A consultation with the } \\
\text { BPK is needed. }\end{array}$ \\
\hline
\end{tabular}

Figure 7: Respondents' responses on the fifth guiding question 
The responses recorded in the figure 7 indicates whether or not the five respondents can decide to what extent the readers are prepared to accept the authors' arguments, opinions, or conclusions. In responding to the fifth guiding question, \#R1 writes textual conclusion which is drawn by the author. It is unwillingly found that \#R1 is unable to check readers' readiness to accept the authors' arguments, opinions, or conclusions.

Differently, \#R2 writes that in the first article, the author concludes that a consultation with $\mathrm{BPK}$ and related ministers is needed to decide LPG price hike policy. In this text, the author implies that the author urges the reader to believe that government is not guilty regarding LPG price hike policy. It is proven by government early action asking pertamina to soon review the policy. And in responding to the second article, he argues that Hatta and Jero must have consulted with President Yudhoyono deciding LPG price hike policy. Therefore, The author implies that readers should assume that it is a lie if the president accused of lying over LPG price hike since Pertamina is a state-owned company. From her responses, it can be drawn that \#R2 has successfully decided to what extent the readers are prepared to accept the authors' arguments, opinions, or conclusions by explaining the implication from the textual conclusion drawn by the author. \#R3, \#R4, and \#R5 write textual conclusion which is drawn by the author. It is similar to \#R1 and unwillingly found that \#R3, \#R4 and \#R5 are unable to check readers' readiness to accept the authors' arguments, opinions, or conclusions.
In conclusion, the five respondents are still confused to check readers' readiness to accept the authors' arguments, opinions, or conclusions. Although they can generally identify the textual conclusion made by the author, they seem failed to reveal what it implies for the readers.

Semi-structured interview is conducted to reveal students' perspective on how students' metafunction competence corresponds with their critical reading. The findings show that all respondents agree that students' metafunction competence help them to read critically. \#R1, \#R2 and \#R3 believe that students' metafunction competence can be the way or guidelines to develop someone's critical reading skill. It is because by learning functional grammar, not only the meaning of words or sentences that they gets. They can get the text as a whole: the meaning, function and the structure of the text. Similarly, \#R3 argues that three systems of metafunction including transitivity system, mood and modality and theme-rheme system help her to read critically. \#R5 argues that she can know the context of the text in a whole. It means that readers can know the purpose of the writer and the reason why she or he write a text. In conclusion, readers can be more critical in reading a text.

\section{Quantitative Analysis}

Quantitative analysis used to discover the correlation between students' metafunction competence and their critical reading. Pearson correlation is applied using SPSS Statistics to do the analysis. The result of the analysis presented figure 8 .

\begin{tabular}{llcc}
\hline & & Students' Metafunction Competence & Critical Reading \\
\hline $\begin{array}{l}\text { Students' Metafunction } \\
\text { Competence }\end{array}$ & Pearson Correlation & 1 & $.977^{* *}$ \\
\cline { 2 - 4 } & Sig. (2-tailed) & 5 & .004 \\
\cline { 2 - 4 } & $\mathrm{N}$ & $.977^{* *}$ & 5 \\
\hline $\begin{array}{l}\text { Critical } \\
\text { Reading }\end{array}$ & Pearson Correlation & .004 & 1 \\
\cline { 2 - 4 } & Sig. (2-tailed) & 5 & 5 \\
\cline { 2 - 4 } & $\mathrm{N}$ & & 5 \\
\hline
\end{tabular}

**. Correlation is significant at the 0.01 level (2-tailed).

Figure 8: Correlation between students' metafunction competence and critical reading

It is found that the correlation between students' metafunction competence and their critical reading is 0.997 . It means that there is a correlation between students' metafunction 
competence and their critical reading. Since the output is positive and clearly greater than (>) 0.5, it also means that the more students possess metafunction competence, the more students can read critically. means that students metafunction competence closely correlates with their critical reading.

Secondly, the significance (2-tailed) gained from the test is 0,004 . It is clearly less than $(<) 0,01$ supporting that students' metafunction competence and their critical reading correlate. The correlation itself is significant at the 0.01 level (2-tailed). These findings suggest that increased levels of students' metafunction competence are associated with their critical reading. The metafunction competence tends to be significantly associated with critical reading. In this context, students' metafunction competence plays as their textual experiences which determine their future textual experiences, including but not limited to their critical reading. As suggested by Smith (2003) \& Lehtonen (2000) that the complexity of readers to texts are not defined by the text itself, but also by readers' own position: their entire resources of textual and non-textual knowledge and experience.

\section{Relationship between students' metafunction competence and their critical reading}

The findings also discover that the three strands of metafunction competence correspond with the characteristics of critical reading. That is why the students' metafunction competence is positively correlated with their critical reading. The correspondence is presented in figure 9 .

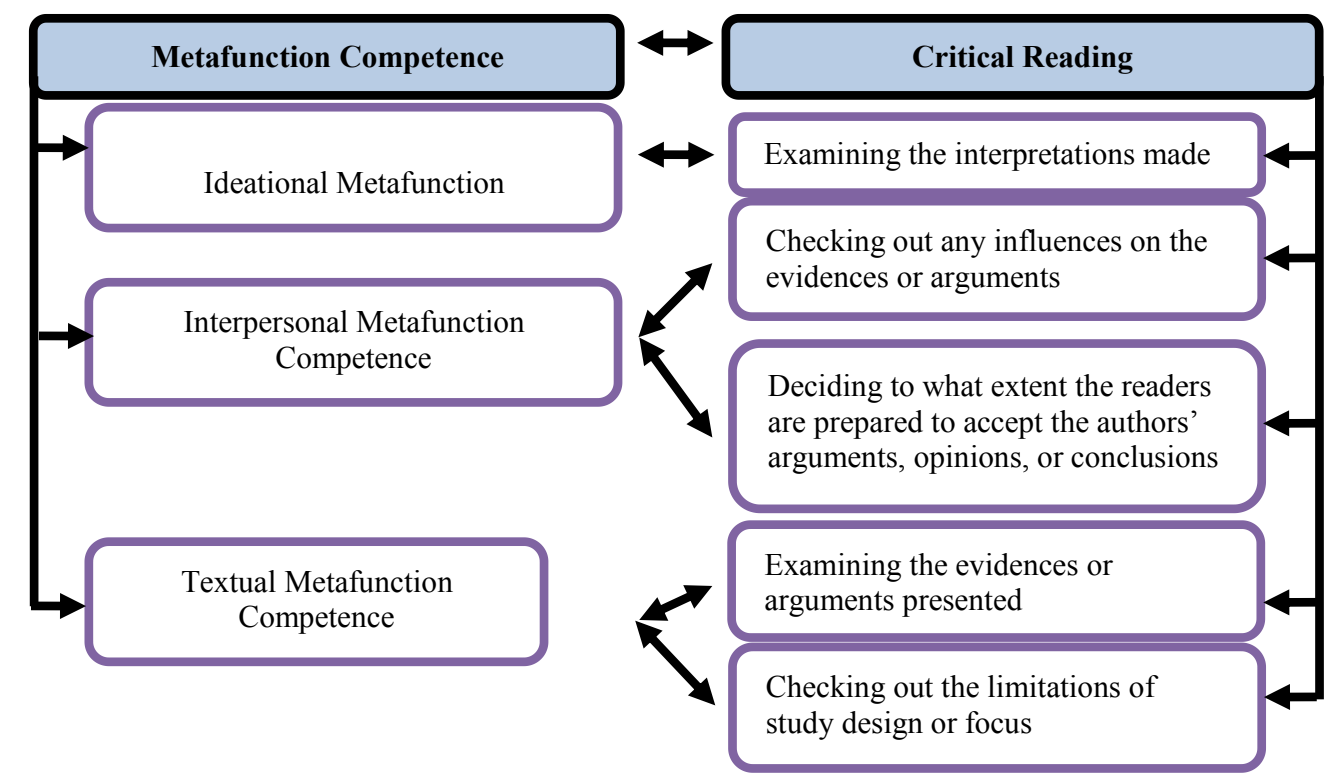

Figure 9: The correspondence between students' metafunction competence and their critical reading

The ideational metafunction competence corresponds with one of the characteristics of critical reading that is reader examines the interpretations made by the authors. Ideational metafunction, as stated by \#R4, helps her to reveal who does what to whom in what circumstance. The knowledge to reveal the writer's/speaker relationship to the subject matter, what the text is about and the language that is used to talk about the world becomes important to examines the interpretations made by the authors.

The transitivity system which is used to reveal ideational metafunction competence deals with participants, processes and 
circumstances. Those three elements are considerably chosen. Therefore, a conclusion can be drawn that the better student possesses ideational metafunction competence, the better student reveals the interpretation made by the authors.

The interpersonal metafunction competence corresponds with two of the characteristics of critical reading those are reader decides to what extent the readers are prepared to accept the authors' arguments, opinions, or conclusions and checks out any influences on the evidences or arguments. Basically, interpersonal metafunction competence refers to the competence to reveal how the writer indicates his/her relationship with the reader, what his/her attitude to the subject matter of the text is, and what parts of grammar can be identified as enablers of interaction.

The competence to reveal how the writer indicates his/her relationship with the reader makes the reader decide to what extent he/she is prepared to accept the authors' arguments, opinions, or conclusions. Moreover, the student's competence to reveal the author's attitude to the subject matter of the text is and what parts of grammar can be identified as enablers of interaction help him/her to check out any influences on the evidences or arguments.

The textual metafunction competence deals with student's competence to reveal what role language is playing in the interaction, how the text is organized, what kind of text is being made and what the channel of communication is. This competence corresponds with two of the characteristics of critical reading i.e. reader checks out the limitations of study design or focus, and examines the evidences or arguments presented.

Theme-rheme system investigates the choice of the theme and coherence of the text. Therefore, what this study shows is that student's competence to investigate the theme of every single clause help him/her to check out the limitations of study design or focus. In addition, student's competence to identify the coherence of the text also helps him/her to examine the evidences or arguments presented in the text.

\section{CONCLUSION}

What this study shows is that students' metafunction competence and their critical reading correlate due to the significance that is gained from the test $(0,004)$ is less than $(<)$ 0,01 . Moreover, it can be concluded that students' metafunction competence and their critical reading correlate positively. It is proven by the correlation output (0.977) which is clearly greater than (>) 0,5 . This means that students metafunction competence closely correlates with their critical reading. Therefore, the more students possess metafunction competence, the more students can read critically. In the other words, students' metafunction competence develops their critical reading ability. The better student's metafunction competence, the better student's critical reading. It is corresponding with the conclusion which is drawn by Bumela (2011) that the initial formation of meaning is also largely influenced by reader's expectations and background knowledge. Hereby, students' metafunction competence plays as background knowledge of the students to recognise the features of the texts and identify the metafunctions of the texts which is beneficial as the departure for the critical reading to discover what appears and what lies behind the text.

\section{References}

Anderson, D. (2011). Write now. Chapel Hill: Longman.

Bumela, L. (2011). The metafunctions revealed: EFL learners' experience in making sense of the text. Conaplin Journal 2, 21-30.

Coffin, C. (2006). English grammar in context, book 3 : Getting practical. Maidenhead: The Open University.

Eggins, S. (1994). An introduction to systemic functional linguistics. London: Pinter Publishers.

Gerot, L., \& Wignell, P. (1994). Making Sense of functional grammar. New South Wales: Antipodean Educational Enterprises.

Halliday, M.A.K. (1985). An introduction to functional grammar. London: Edward Arnold. (1994). An introduction to functional grammar (Eds). London: Edward Arnold. (2003). Architecture of human language. In Jonathan, W (Eds). On Language and Linguistics, 29.

Jones, R.H and Lock, G. (2011). Functional grammar in the ESL classroom: noticing, exploring and practising. London: Palgrave Macmillan. 
Knapp, P., \& Watkins, M. (2005). Genre, text, grammar: Technologies for teaching and assessing writing. Sydney: University of New South Wales Press.

Learning Development at the University of Leicester. (2009). What is critical reading?. Retrieved January 05, 2014, from http://www2.le.ac.uk/ offices/ld/resources/pdfs-of-studyguides/writing-skills-pdfs/critical-readingv1\%200.pdf

Lehtonen, M. (2000). The cultural analysis of text. London: Sage Publication Ltd.

Maulana, J.A. (2014). Exploring the critical reading sheet: A tool for students' meaning making practice: A paper presented in the 6th National English Language Teachers and Lecturers (NELTAL) Conference on success stories in English language teaching (or learning), held in Malang, Indonesia, March 29, 2014.
O’Halloran, K.A. (2006). English grammar in context, book 2: Getting inside English. Maidenhead: The Open University.

Smith, C.S. (2003). Modes of discourse: The local structure of text. Cambridge: Cambridge University Press.

Thompson, G. (2004). Introducing functional grammar. London: Arnold.

Wallace, C. (2003). Critical reading in language education. New York: Palgrave McMillan.

Yudhoyono, S. B. (2014, January 05). SBY asks pertamina to review LPG price hike. The Jakarta Post. Retrieved from http://www.thejakartapost. com/news/2014/01/05/sby-asks-pertaminareview-lpg-price-hike.html

Yudhoyono, S. B. (2014, 2014, January 05). Govt accused of lying over LPG price hike. The Jakarta Post. Retrieved from http://www.thejakartapost.com/ news/2014/01/05/govt-accused-lying-over-lpgprice-hike.html 